周術期二次救命処置トレーニング (ALS-OP)の必要性

\title{
麻酔関連偶発症例調査の結果から手術室で必要とされる 二次救命処置を考える-ALS-OP循環編一
}

$\begin{array}{cc}\text { 羽場政法 }^{* 1} & \begin{array}{c}\text { 駒澤伸泰 } \\ \text { 上藤原俊介 }{ }^{* 2} \\ \text { 上浩順 }\end{array}{ }^{* 3} \text { 水本一弘 } \\ \end{array}$

[要旨］日本麻酔科学会が行っている麻酔関連偶発症例調査によると手術による大量出血は, 死亡 原因の上位を占めている. また術中発症の病態として「急性冠症候群」は発症頻度も高く，心停止 への移行頻度が高い. 二次救命処置講習会で学んだことを実践するには, 二次救命処置講習会受講 により, 適切な知識を得た後, 1. 手術室の状況に合った患者モデルの使用, 2. 原因疾患に応じ た知識の習得, 3. 症例に対応するための環境整備の検討, 4. メディカルスタッフとのチームコ ミュニケーションを学ぶ方法が必要である. Problem-based Learning Discussion形式のトレ 一ニングは, それぞれの受講生に応じた知識の体系化が可能であり, ディスカッションを通してチ ームコミュニケーション(ノンテクニカルスキル)をつくることも期待される. チーム医療を推奨す る周術期管理において，これらのPBLD形式のツールが医療安全向上に貢献できるのではないか と考えた.

キーワード : 大量出血, Problem-based Learning Discussion, ノンテクニカルスキル, 二次 救命処置

\section{I 日本麻酔科学会の偶発症例調査から}

日本麻酔科学会では，麻酔関連偶発症例調査専門 部会が中心となり麻酔科認定病院の麻酔科が管理し た管理症例を対象として, 1992 年より, 年次別の「麻 酔関連偶発症例調査」を行っている ${ }^{11}$. 麻酔関連偶 発症例とは，「原因の如何を問わず，麻酔がかかっ ている状況下で生命危機状態となった症例」を指し， 麻酔中に患者の生命が危機的状態にさらされた症例 そのものを検証し, 結果的に何が原因であったのか を特定した上で，再発防止策やガイドラインなどを

${ }^{* 1}$ 国保日高総合病院麻酔科

*2 大阪医科大学麻酔科学教室

${ }^{* 3}$ 昭和大学病院麻酔科

${ }^{* 4}$ 和歌山県立医科大学附属病院医療安全推進部
作成することを目的としている。

2004年〜2008年に行われた第三次偶発症例調査 によると，心停止ならびに高度低血圧の最大の原因 は，術前合併症としての出血性ショックと手術によ る大出血である。また，偶発症が 100 症例以上報告 された原因の中で心停止の割合が $30 \%$ を超えたも のに, 術前合併症としての出血性ショック, 心筋梗 塞・冠虚血, 術中発症の病態としての急性冠症候群, 肺塞栓があげられている。

心停止後の転帰は原因によって大きく異なり，手 術による大出血の場合には $70 \%$ は死亡し，後遺症

$\begin{array}{ll}\text { 著者連絡先 } & \text { 羽場政法 } \\ \text { T } 644-0002 & \text { 和歌山県御坊市薗 116-2 }\end{array}$ 国保日高総合病院麻酔科 
なく回復した症例はわずか $20 \%$ あっわた。心停止 が 100 症例以上報告された原因の中で死亡率が $50 \%$ を超えたものに，術前合併症としての心筋梗塞・冠 虚血がある。

これら偶発症例の心停止回避として, 日本麻酔科 学会は産科危機的出血や危機的出血の対応ガイドラ インのポスターを作成し注意喚起を行い2).3)，専門 医申請にあたり二次救命処置講習会の受講を必須と している.

\section{II 周術期循環合併症領域における 二次救命処置訓練の必要性}

偶発症例の心停止回避として, 二次救命処置講習 会で得られる知識や技術は麻酔科領域において重要 であるが，講習会で提示される患者モデルは，呼び かけ・脈拍・心電図による循環評価と対応，呼吸評 価に続くバッグバルブマスクでの気道確保が中心と なる。手術室内の偶発症例においては気管挿管によ る気道確保と動脈圧ラインや心拍出量測定等の高度 なモニターが使用されていることが多く，意識は麻 酔により遮断されている。これらを勘案すると日常 の麻酔業務の中では，二次救命処置講習会で提示さ れた患者モデルは少ないと考える. 米国麻酔科学会 においても，手術室の状況に応じた二次救命処置シ ナリオAnesthesia Advanced Circulatory Life Support(A-ACLS) をe-Learning形式で行っている. われわれが二次救命処置講習会で学んだことを実践 するには，二次救命処置講習会受講により，適切な 知識を得た後, 1 . 手術室の状況に合った患者モデ ルの使用，2. 手術室で頻度の高い原因疾患に応じ た知識の習得，3，症例に対応するための環境整備 の検討，4.メディカルスタッフとのチームコミュ ニケーション(ノンテクニカルスキル)を学ぶ方法が 必要ではないかと考えた。

\section{PBLD方式の利点}

Problem-based Learning Discussion(PBLD)形式
のトレーニングは一方的な知識の押しつけではな く，ディスカッションを行うことによりそれぞれの 受講生に応じた知識の体系化が可能であり ${ }^{4)}$ ，同施 設内の麻酔科医，外科医，看護師，臨床工学技士， 薬剤師とともにディスカッションすることでチーム コミュニケーションを作りノンテクニカルスキルの 向上にも役立つ。同施設内でのディスカッションは 施設環境整備の検討も期待される。マネキンを使用 したトレーニングに比べると，コストがかからず， 必要物品も少なく，開催場所も制限されず，そして ファシリテーションに必要なスタッフ数も少なく済 むという運営側のメリットも大きい。チーム医療を 推奨する周術期管理においてこれらのシミュレーシ ヨンツールが医療安全向上に貢献できるのではない かと考え，周術期二次救命処置講習会の開発と開催 に至つた ${ }^{5), 6)}$.

\section{ALS-OP循環編の開発}

偶発症例調査から周術期における循環合併症への 対策を目的としたPBLD形式のシナリオを以下に紹 介する。

\section{くスライドの形式 >}

一人の患者の経過を時系列に作成した。場面ごと の患者状態をイメージできるよう，患者の情報を提 示し，患者評価や次に検討すべき題材の問題提起を 行った(図1)。次のスライドでは問題提起された内 容に対してディスカッションが膨らむよう資料の提 供を行った(図2)。

<ALS-OP循環編の各シナリオのテーマと目標(表 1) > (1)右冠動脈心筋梗塞への対応

非心臓手術における合併心疾患の術前評価をガイ ドライン に沿って行うことができる。心筋梗塞の 診断を確定できる。右冠動脈閉塞による下壁心筋梗 塞の特殊性を理解し，治療を行える。循環ショック 時に対応できる。早期の再還流療法の必要性 ${ }^{8}$ を理 解する。

(2)左冠動脈心筋梗塞への対応 


\section{症例提示 $1-4$}

- 麻酔科後期研修医1名、研修医1名、看護師2名、臨床工学技士 が駆けつけた。

- 12誘導心電図検查、経胸壁エコ一、血液検查(CKMB分画の上昇、 トロポニンT)、動脈血液ガス分析の施行を指示した。

- 心電図上 1 度房室ブロックと II III、aVFでST上昇、右側胸部誘導 でV4RのST上昇

・ 経胸壁エコーでは下壁の壁運動異常

・ トロポニンT検査陽性

- 動脈血液ガス分析ではPaO2 530mmHg PaCO2 44mmHg(EtCO2 $40 \mathrm{mmHg}$ )

・あなたは右冠動脈の心筋梗塞と診断した。

・ 今後の治療方針は?

図1 症例提示(参考スライド)

\section{右冠動脈閉塞による下壁心筋梗塞の治療}

目的筋酸素消費量を低下させる。 心筋に酸素を届ける

- IABP(大動脈内バルーンパンピング)

・昇圧薬(ドパミン、ドブタミン、ノルアドレナリン)

・初回1-2Lの輸液。その後250-500m|のボーラス投与

(高い压と大量輸液は右室の機能と回復をさらに損なう可能性がある。最適な前 貝荷を達成でるよう、臨床所見とパイルルサンを見なが翰液投与を行ゔ

・ ペースメーカー(房室ブロックに対し)

・前負荷を軽減する治療(硝酸薬、モルヒネ、利尿薬、ACEI) はさけるべき

ニトログリセリンについて

心筋梗塞患者に硝酸薬をルーチーンに静注、経口投与、局所投与する事を

支持する決定的なエビデンスはない。循環血液減少、低血圧の兆候のある

患者には有用でない。

図2 ディスカッション資料(参考スライド)

非心臓手術における合併心疾患の術前評価をガイ ドライン ${ }^{7)}$ に沿って行うことができる。 心筋梗塞の 診断を確定できる. 左冠動脈閉塞による心筋梗塞の 治療法を行える。循環ショック時に対応できる。早 期の再還流療法の必要性を理解する.
(3)深部静脈血栓症による肺塞栓症への対応 ${ }^{9)}$ 術前評価時に深部静脈血栓症のリスク分類を行え る。必要に応じて深部静脈血栓症スクリーニング検 査を行える。肺塞栓症の可能性と鑑別すべき疾患を 検討できる。肺塞栓症疑い状態で対症療法 (補助療 
表1 ALS-OP 循環編のシナリオ, 学習目標と参照ガイドライン

\begin{tabular}{|c|c|c|c|}
\hline シナリオのテーマ & シナリオの内容 & 学習目標 & 参考資料 \\
\hline $\begin{array}{l}\text { 右冠動脈心筋梗塞 } \\
\text { への対応 }\end{array}$ & $\begin{array}{l}\text { 術中心筋梗塞発生に } \\
\text { 対し冠動脈梗塞部位 } \\
\text { 診断と右冠動脈心筋 } \\
\text { 梗塞に必要な治療を } \\
\text { 行う }\end{array}$ & $\begin{array}{l}\text { 非心臓手術における合併心疾患の評価と } \\
\text { 管理に関するガイドライン. 循環ショッ } \\
\text { ク時の対応. 鑑別疾患. 診断確定方法. } \\
\text { 右冠動脈閉塞による下壁心矨梗塞の治 } \\
\text { 療. 早期の再還流療法の必要性. }\end{array}$ & $\begin{array}{l}\text { 非心臓手術における合併心疾患の評価と } \\
\text { 管理に関するガイドライン } \\
\text { 版) } \\
\text { ACLS EP マニュア年改訂 } \\
\text { 周術期管理チームテキリソーステキスト } \\
\end{array}$ \\
\hline $\begin{array}{l}\text { 工冠動脈心筋梗塞 } \\
\text { の対応 }\end{array}$ & $\begin{array}{l}\text { 術中心筋梗塞発生に } \\
\text { 対し冠動脈梗塞部位 } \\
\text { 診断と左冠動脈心筋 } \\
\text { 梗塞に必要な治療を } \\
\text { 行う }\end{array}$ & $\begin{array}{l}\text { 非心臓手術における合併心疾患の評価と } \\
\text { 管理に関するガイドライン. 循環ショッ } \\
\text { ク時の対応. 鑑別疾患. 診断確定方法. } \\
\text { 左冠動脈閉塞による心筋梗塞の治療. 早 } \\
\text { 期の再還流療法の必要性. }\end{array}$ & $\begin{array}{l}\text { 非心臓手術における合併心疾患の評価と } \\
\text { 管理に関するガイドライン } \\
\text { 版) } \\
\text { ACLS EP マ2008年改訂 } \\
\text { 周術期管理チームテルリリンーステキスト }\end{array}$ \\
\hline $\begin{array}{l}\text { 部静脈血栓症に } \\
\text { る肺塞栓症への } \\
\text { 応 }\end{array}$ & $\begin{array}{l}\text { 術中肺塞栓症の診断 } \\
\text { を行いながら同時に } \\
\text { 対症療法を行う }\end{array}$ & $\begin{array}{l}\text { 静脈血栓症のリスク分類. 鑑別疾患. 肺 } \\
\text { 塞栓症の治療開始時期. 補助療法. 診断 } \\
\text { 確定方法. 深部静脈血栓症スクリーニン } \\
\text { グ検査 }\end{array}$ & $\begin{array}{l}\text { 肺血栓塞栓症 / 深部静脈血栓症予防ガイ } \\
\text { ドライン } \\
\text { ACLS EP マニュアルリソーステキスト }\end{array}$ \\
\hline $\begin{array}{l}\text { 量出血による心 } \\
\text { 止への対応 }\end{array}$ & $\begin{array}{l}\text { 手術操作による危機 } \\
\text { 的大量出血を認識 } \\
\text { し, チームとして治 } \\
\text { 療を行う }\end{array}$ & $\begin{array}{l}\text { 効率的な血液準備方法. 循環のモニター } \\
\text { リング. 危機的出血発生の認識. 異型適 } \\
\text { 合血の使用法. 急速輸血装置使用時の注 } \\
\text { 意. 大量輸血による副作用・合併症. }\end{array}$ & $\begin{array}{l}\text { 危機的出血への対応ガイドライン } \\
\text { 輸血療法の実施に関する指針(改定版) } \\
\text { 教育ガイドライン改訂第 } 2 \text { 版 } \\
\text { 安全な麻酔のためのモニター指針 }\end{array}$ \\
\hline $\begin{array}{l}\text { 坠科的危機的出血 } \\
\text { こよる心停止への } \\
\text { 讨応 }\end{array}$ & $\begin{array}{l}\text { 妊婦の特殊性を理解 } \\
\text { し, 帝王切開手術に } \\
\text { 伴う大量出血を認識 } \\
\text { し, チームとして治 } \\
\text { 療を行う }\end{array}$ & $\begin{array}{l}\text { 妊婦の特殊性の認識. 大量出血が予測さ } \\
\text { れる産科疾患. ショックインデック. } \\
\text { 産科危機的出血の認識. 産科DIC. 危機 } \\
\text { 的出血発生の認識. 異型適合血の使用法. } \\
\text { 大量輸血による副作用・合併症. }\end{array}$ & $\begin{array}{l}\text { 産科危機的出血への対応ガイドライン } \\
\text { 危機的出血への対応ガイドライン } \\
\text { 輸血療法の実施に関する指針(改定版) } \\
\text { 教育ガイドライン改訂第2版 }\end{array}$ \\
\hline $\begin{array}{l}\text { 悪性高熱症による } \\
\text { 高カリウムでの心 } \\
\text { 停止への対応 }\end{array}$ & $\begin{array}{l}\text { 悪性高熱症を認識 } \\
\text { し, チームとして治 } \\
\text { 療と対症療法を行う }\end{array}$ & $\begin{array}{l}\text { 悪性高熱症を誘発する可能性のある薬 } \\
\text { 物. 悪性高熱症の初期, 中期, 後期にお } \\
\text { ける臨床所見と臨床経過. MHCGScale. } \\
\text { 悪性高熱の治療. 対症療法 }\end{array}$ & $\begin{array}{l}\text { 緊急時の治療法 悪性高熱症 2003年 } \\
\text { Br J Anaesth } 2000 ; 85: 118-28 . \\
\text { Hopkins PM } \\
\text { Anesthesiology } 1994 ; 80: 771-9 . \\
\text { Larach MG, Localio AR, Allen GC, et al. } \\
\text { ACLS EP マニュアルリソーステキスト }\end{array}$ \\
\hline
\end{tabular}

法)が行える。最終的な肺塞栓症診断確定方法と治 療を理解する。

(4)大量出血による心停止への対応 ${ }^{2)}$ 10)

麻酔計画を立てるために必要な，効率的な血液準 備方法を理解し, 必要な循環のモニターリングを行 える，危機的出血発生を認識できる，異型適合血を 状況によって適切に使用できる。急速輸血装置使用 時の注意点を理解する. 危機的出血時のチームワー クの重要性を理解する。大量輸血による副作用・合 併症を理解する。

(5)産科的危機的出血による心停止への対応 ${ }^{2), 3)}$ 10)

産科DICを含女妊婦の特殊性を理解する。ショ ックインデックスを使用し患者を評価できる。産科
危機的出血発生を認識できる。異型適合血を状況に よって適切に使用できる。産科危機的出血時のチー ムワークの重要性を理解する。大量輸血による副作 用・合併症を理解する。

(6)悪性高熱症による高カリウムでの心停止への対応 悪性高熱症を誘発する可能性のある薬物を理解す る。悪性高熱症の初期, 中期, 後期における臨床所 見と臨床経過を理解する ${ }^{11)}$. MHCGScale ${ }^{12)}$ による悪 性高熱の確定診断が行える。悪性高熱の治療，対症 療法を行える。 


\section{ALS-OP 循環編の定期的な見直しと システムの構築}

ALS-OP循環編の初期シナリオを作成した.
の試みは完了したのではなく現在進行形である. 後も周術期管理チームに必要な知識を導入し，さら に洗練されたコース作りが必要と考える。そのため には，コース受講が受講生の意識に与える影響やプ レポストテスト等を通じて学習効果の検討, 講習会 の検討も必要である ${ }^{13) ~ 15)}$.

また，これらのツールは限られた施設で独占され るのではなく，どこでも，誰でも使用が可能なよう に, 麻酔科関連学会から提供されるシステムが構築 されれば，学会が目指す麻酔科専門医の育成につな がるのではないかと考えている。

\section{結 語}

二次救命処置の手術室トレーニングとして PBLD 形式の患者シナリオを作成した。チーム医療を推奨 する周術期管理において，これらのシミュレーショ ンツールが医療安全向上に貢献できるのではないか と考える.

\section{参考文献}

1）日本麻酔科学会: 日本麻酔科学会偶発症例調查 第三次 調查. (https://member.anesth.or.jp/App/datura/news 2010/r20100301.html)

2）日本麻酔科学会: 危機的出血への対応ガイドライン. (http://www.anesth.or.jp/guide/pdf/kikitekiGL2.pdf)

3）入田和男, 稲田英一: 産科危機的出血への対応ガイド ライン. 麻酔 $60: 14-22,2011$

4) Albanese MA, Mitchell S : Problem-based learning : a review of literature on its outcomes and implementation issues. Acad Med $68: 52-81,1993$

5）駒澤伸泰, 羽場政法, 上嶋浩順ほか：専門領域に応用 できるALS コースの必要性一周術期 ALS (ALS-OP)の 提案一. 日臨麻会誌 $35: 538-543,2015$

6）駒澤伸泰, 藤原俊介, 羽場政法ほか：周術期二次救命 処置トレーニング(ALS-OP)の開催経験．麻酔 64 ： $562-565,2015$

7) 循環器病の診断と治療に関するガイドライン $(2007$ 年度 合同研究班報告）：非心臟手術に扔ける合併心疾患の評 価と管理に関するガイドライン (2008年改訂版)

8) American Heart Association : ACLS for Experienced providers Manual and Resource Text 11章. 2013, 175-234

9) 循環器病の診断と治療に関するガイドライン $(2008$ 年度 合同研究班報告)：肺血栓塞栓症抢よび深部静脈血栓症 の診断，治療，予防に関するガイドライン (2009年改訂 版 ). (http://www.j-circ.or.jp/guideline/pdf/JCS2009_ andoh_h.pdf)

10）厚生労働省医薬食品局血液対策課：輸血療法の実施に 関する指針(改定版). (http://www.mhlw.go.jp/newinfo/kobetu/iyaku/kenketsugo/yuketuchiryou07/dl/ yuketuchiryou07a.pdf)

11) Hopkins PM : Malignant hyperthermia : advances in clinical management and diagnosis. Br J Anaesth 85 : 118-128, 2000

12) Larach MG, Localio AR, Allen GC, et al. : A clinical grading scale to predict malignant hyperthermia susceptibility. Anesthesiology 80 : 771-779, 1994

13) Komasawa N, Fujiwara S, Atagi K, et al. : Effects of a simulation-based sedation training course on non-anesthesiologists' attitudes toward sedation and analgesia. J Anesth $28: 785-789,2014$

14) Naik VN, Brien SE : Review article : simulation : a means to address and improve patient safety. Can J Anaesth $60:$ 192-200, 2013

15）羽場政法, 駒澤伸泰, 藤原俊介ほか：安全な鎮静・鎮 痛法の講習会の改良に向けて一プレテスト・ポストテ ストによる習熟度評価の導入一。 日臨麻会誌 $34 ： 583-$ 587, 2014 


\title{
Circulatory Crisis Management in the Operating Room Based on Anesthesia Occasional Case Reseach
}

\author{
Masanori HABA*1, Nobuyasu KOMASAWA ${ }^{* 2}$, Shunsuke FUJIWARA*2, \\ Hironobu UESHIMA*3, Kazuhiro MIZUMOTO*4 \\ ${ }^{* 1}$ Department of Anesthesiology, Hidaka General Hospital \\ ${ }^{* 2}$ Department of Anesthesiology, Osaka Medical College \\ ${ }^{* 3}$ Department of Anesthesiology, Showa University Hospital \\ ${ }^{* 4}$ Department of Anesthesiology, Wakayama Medical University
}

\begin{abstract}
Massive hemorrhaging and acute myocardial infarction can cause crises in the operating room, so a simulation-based educational course for dealing with perioperative crise (ALS-OP) based on occasional case research in anesthesia and/or anesthesia educational guidelines may help improve medical safety in the operating room. To maximize the performance of advanced life support training in the operating room, the course content should be constructed using operating room situations, scenarios based on special operating room situations, environmental factors, and smooth communication with medical staff. Training that employs problem-based learning and discussion can be adjusted to the level of each participant, and non-technical skills such as team communication can also be cultivated. Problem-based learning and discussion may help improve medical safety in the operating room.

Key Words : Life-threatening hemorrhage, Problem-based learning discussion, Non-technical skill, Advanced life support
\end{abstract}

The Journal of Japan Society for Clinical Anesthesia Vol.36 No.2, 2016 